\title{
The effect of marketing and technostructural intangible resources in the Nigerian banking sector
}

\author{
Samuel Adedoyin $^{\mathrm{a}^{*}}$ and Charity Ezenwakwelu ${ }^{\mathrm{b}}$
}

${ }^{a}$ Benson Idahosa University, Benin City, Nigeria

${ }^{b}$ University of Nigeria Nssuka, Enugu State, Nigeria

\begin{tabular}{l}
\hline C H R O N I C L E \\
\hline Article history: \\
Received: July 232019 \\
Received in revised format: July \\
282019 \\
Accepted: September 2, 2019 \\
Available online: \\
September 2, 2019 \\
\hline Keywords: \\
Competitive Advantage \\
Marketing \\
Technological and Structural In- \\
tangibles
\end{tabular}

\section{A B S T R A C T}

\begin{abstract}
This study analyzes the effects of intangible resources on competitive advantage in the banking sector of Nigeria. The marketing related, technological and structural dimensions of intangibles are employed while differentiation and cost leadership strategy are used as components of competitive advantage. The population of the study consists of bank employees of ten deposit money banks in Benin City, Nigeria. A sample size of 300 is adopted for this study. The instrument is a modified 35 item structured questionnaire previously validated by other studies. The study uses confirmatory factor analysis and structural equation technique to evaluate the validity of the measurement and structural model. The hypothesized relations are tested using regression analysis. The results confirm that marketing related, technological and structural categories of intangible resources promoted competitive advantage. It is recommended that bank management should promote the development of their intangible resources.
\end{abstract}

\section{Introduction}

Intangible resources broadly describe all intellectual based materials such as information, experience, intellectual property, etc. and represents the collective brainpower that can be harnessed to generate economic returns (Steward, 2010). Blair and Wallman, (2001) defined intangibles as non-physical components owned by the organization useful in manufacturing goods or delivering services, with expectation of generating future economic gains for the owners of those factors. It is sometimes used interchangeably with intellectual capital and it refers to the aggregate knowledge within an organization at a given time and therefore depicts a snapshot presentation of what a corporate entity has learnt in a cognitive sense (Husain et al., 2013). The intellectual capital comprises the knowledge, innovation, favorable relationships and expert abilities owned by the firm; and it can increase its market competitiveness (Edvinsson, 2007; Satt \& Tamek, 2017). It embraces all kinds of intangibles utilized by the firm and is an important resource that promotes the firm competitiveness and affect organizational performance (MERITUM, 2002; Sabramaniam \& Youndt, 2005; Chahal \& Bakshi, 2014). The beneficial role of intangibles in promoting competitive advantage and eventual organizational performance in sectors such as banking, pharmaceutical, SMEs and manufacturing, is evidenced in literature as the intangible resource discourse is receiving increasing global attention as they have been identified to be a prominent success determinant in this knowledge age (Teixeira et al., 2012; Serenko, et al. 2009). Scholars like Stewart (1999), Lev (2001, 2003), Guenther et al. (2005) opine that concepts like intellectual capital management, dynamic capabilities, innovation and knowledge management highlight the growing importance of intangibles as silent platforms for developing competitiveness in organizations. The intangibles are known to provide real financial benefit that may not be easily quantifiable such as favorable brand equity and profitable customer relationships (Lev, 2001); they serve as a tool for competitiveness, enhance organizational growth and development, generate profitable externalities through synergies and alliances with other organizations, generate revenue through royalties and rents paid from contracts arranged and afford other advantages once the firms capability is built on intangible resources.

\footnotetext{
* Corresponding author.

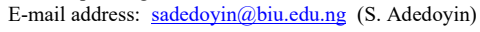


Montresor et al. (2014) cited in Satt and Tamek (2017) report that in some organizations over $70 \%$ of the company value emanates from intangibles. Studies have shown that the strategic combination and management of these intangible resources improve organizational competitiveness and long run performance (Okpara, 2015; Khalique et al., 2018). Kaufman and Schneider (2004) assert that for the effective management of intangibles, it is necessary to label and categorize different intangible resources available to the organization. From the literature, intangibles in organizations are diverse and includes components such as managerial capabilities, innovation abilities, knowledge base and know how, corporate routines, ideas, scientific capabilities, knowledge capital and intellectual property, customer reputational capital, network/ client reputation, brand name, product quality, durability and reliability, firm attributes, information, the corporate knowledge and codified experience, values system, perceptions and feelings differentiating firms from one another (Hatch \& Dyer, 2004; Wade \& Hulland, 2004). Adler and Kwon, (2002) include the symbolic capital which describes the reputation of the company such that its own values and visions are the ones considered acceptable and legitimate by stakeholders, and an innovative culture in workers beneficial in pursuance of sustainable competitive advantage and in managing industry challenges (Hatch \& Dyer, 2004; Wade \& Hulland, 2004; Edvinsson et al., 2010; Perrini \& Vurro, 2010). Other intangibles are trademarks and associated materials, company websites, color and package design, market share, market potential and synergies, patents, brands, goodwill, franchises, secret processes and recipe, data bases, the organizational culture and the technology, reputation, its distribution channels and business relationships built over the years (Gomez-Mejía \& Balkin, 2002; Perez \& Famá, 2006). Starovic and Marr (2003) opine that the intangible resources may be grouped into the human, the organizational and the relational component; Steward (2010) categorized them into human, structural and customer capital while Perrini and Vurro (2010) grouped intangibles into human, structural/organizational, relational and symbolic/reputational intangibles. The International Accounting Standards Board, (IASB) suggests that intangibles may be categorized into the marketing-related, human, structural, customer based, contract based, technological based and the artistic related intangibles.

The thrust of this paper is to ascertain the effects of the marketing and technostructural intangible resources on competitiveness of the sampled banks. This paper concentrates on these dimensions because of the Nigerian banking reforms and the post consolidation exercise of 2005 mandating huge capitalization, the banks in Nigeria have been aggressively involved in marketing and consequently deploy their technological and structural capabilities in trying to outperform the competition. This paper seeks to establish if the banks marketing and technostructural intangible resources wields significant effects on competitive advantage of the sampled banks in Nigeria more especially as a developing economy.

\subsection{Literature Review and Hypothesis Development:}

\subsubsection{Intangible Resources}

These are all non-physical, abstract and non-monetary factors owned by an organization that can help generate future economic profits. They are controlled / regulated by the organization and in recent times occupy a prime position in the balance sheets of the organizations (MERITUM, 2002; Satt \& Tamek 2017). The intangibles are characterized as unseen, untouchable, difficult to measure and takes time to build. They include copyright, trademarks, trade names, franchise licenses, permit, and goodwill (Satt \& Tamek, 2017). Scholars agree that the intangibles function strategically in contributing to value creation thereby supporting the firms' competitive edge and market performance. (Lev, 2001; Volkov \& Garanina, 2007). Satt and Tamek (2017) report that in some economies, intangibles generate higher proportion of returns than the tangibles resources and afford long term advantages to the organization.

Some studies on intangible factors and sustainable firm performance like Villalonga, (2004) assessed the levels of returns on assets (ROA) of sampled firms in US across different sectors and established that intangibles significantly supported improved performance and argued that intangibles accounted for sustained performance of the firms. Similarly, Perez and Famá (2006) noted that intangibles were responsible for new value aside the regular earnings contributed by the tangible assets. Some scholars have investigated different dimensions of the intangible resources' effects on competitive edge and performance of organizations (e.g. Wade \& Hulland, 2004; Cater \& Cater, 2009; Khalique et al., 2018) in diverse sectors such as manufacturing, banking, SMEs, IT, etc. Also, specific intangible dimensions have been reported to have distinct effects on the performance of organizations e.g. human capital intangibles positively affect performance (Amiri et al., 2010; Khalique et al., 2018); reputational intangibles affect competitiveness and performance and the structural capital affects on competitiveness /performance (Zangoueinezhad \& Moshabaki, 2009; Khalique et al., 2018) etc. This study is imperative and unique as literature shows that majority of the studies on intangibles are from developed and developing economies of the Western and Asian nations and it would therefore be necessary to undertake a study and examine whether we receive the same results in Nigeria as a developing African economy. This research attempts an investigation of the effect of the marketing, technological and structural intangible resources on the competitiveness of the sampled banks.

\subsubsection{Marketing Capital Intangibles}

This category of intangibles are assets connected with the market place. The marketing capital refers to the silent benefits obtainable from the non-material resources associated with the market place. They include the product reputation, strong brands, market share, customer relationships, favorable brand equity, patents, market potential, competition agreements and 
synergies, commercial name, shop sign and distribution networks, trademarks, logos, distinct color, package design, the websites and internet domain names etc. (Pierre, 2011; Kotler \& Armstrong, 2010; Kotler \& Kotler, 2011; Edvinsson \& Malone, 2010; Satt \& Tamek 2017, International Financial Reporting System, IFRS 3). These intangibles help in building a unique identity, maintain customer loyalty, increase sales volumes, and attain cost minimization, aid goal attainment and profitability (Andrews \& De Serres, 2012; Satt, 2015; Satt \& Tamek, 2017). They also influence customers' decision making as they imply customer trust for the products, and satisfy the customer status needs especially with luxury brands. The registered trademarks or service marks of organizations offer legal protection, help identify the producer and differentiate the product or service from that of competing organizations. The patents and trademark offer future economic benefits for its owners as it increases customer patronage and sales volumes, and enables the owners to charge favorable prices as against competing unbranded products (Lev, 2001). The marketing intangibles are strategically important as Boubakri and Ghouma (2008) posit that since they are largely inimitable they afford a platform for competitive advantage. This paper attempts to ascertain if the marketing intangibles would influence competitive advantage in the banking sector in Nigeria using the cost leadership and differentiation component of competitive advantage and hypothesizes that:

H1a. The marketing capital intangibles will positively affect the cost leadership strategy. H1b. The marketing capital intangibles will positively affect the differentiation strategy

\subsubsection{Technology Based Intangibles}

According to McGrattan and Prescott (2008), the technological capital refers to the aggregated know-how resulting from investments in intangibles like $\mathrm{R} \& \mathrm{D}$, brands, and in the organization that is usable both in domestic and foreign operations. The technology describes the operational processes and methods, employed for transformation of input and in generating the desired output and spans the equipment, skills, mechanisms, tools and knowledge (Grigoriev et al. 2014). The technology comprises knowledge connected with accessibility, use and innovation in techniques of production. Technology based intangibles increase by the research and development activities of a firm, by technological adoption and imitation of the technologies of other companies (Fernandez et al., 2000). Technological intangibles include legally protected technology, IT software, process know how, databases including title plants, technological and process know-how, education, experience, and trade secrets (Edvinsson, 2010). The technological intangibles in the form of technical knowledge may be captured and written down into formulae, blueprints or engineering specifications. Organizations endeavor to secure their technological intangibles through legal means afforded by the government to prevent theft or encroachment by unauthorized persons, for an identified time span and enhances economic reward to the inventor (Lev, 2003). Patents provide important benefits especially in IT driven sectors and define ownership of innovation breakthroughs, facilitate knowledge exchanges, aid in preserving monopoly profits and in rewarding combined efforts of an organizations research and development ingenuity, and also enhance access to overseas markets (Fernandez et al., 2000). Porter $(1995,2005,2008)$ posits that firms attain competitive advantage through technological innovations and new methodologies and that the technologies affect the costs reduction and differentiation components of competitive advantage thereby creating enhanced competitiveness for the firm. In view of the above, this study aims to ascertain if the technological intangibles would influence competitive advantage in the banking sector in Nigeria and employs the cost leadership and differentiation component of competitive advantage and hypothesizes that:

H1a. The technological capital intangibles is associated positively with the cost leadership strategy. H1b. The technological capital intangibles is associated positively with the differentiation strategy.

\subsubsection{Structural Intangibles}

The structural/organizational capital is described by Maddocks and Beaney (2002) as the supportive infrastructure, processes and management system of the business that facilitates the performance of tasks and duties of the employees. Youndt and Scott (2004) describe structural capital as the institutional knowledge and coded experience dwelling resident in an organization and is usable through the internal systems, processes, structures, databases and patents. Barnabas et al. (2016) posit that organizations do not operate in vacuum but within certain organized structure and/or system and that this structure/system influences the other forms of intellectual capital. The structural capital enhances innovation, the research and development, information sharing, distribution procedure, corporate culture and structures, and other workplace frameworks and positively influences competitive advantage and performance (Cater \& Cater, 2009; Khalique et al., 2018). This is supported by the study of Okpara (2015) who affirmed that the structural capital affects the performance of firms, that a firm's competitive strength hinges more on its structural capital than on the other dimensions and that the structural capital is a prime platform for enhanced competitiveness and performance of companies. Saeed et al. (2016) however in their own study report an insignificant structural capital efficiency influences on the productivity and profitability of the sampled companies. In view of the above, this study aims to ascertain if the structural intangibles would influence competitive advantage in the banking sector in Nigeria using the cost leadership and differentiation component of competitive advantage and hypothesizes that:

H1a. The structural intangibles is associated positively with the cost leadership strategy. H1b. the structural intangibles is associated positively with the differentiation strategy. 


\subsubsection{Statement of Hypothesis and Conceptual framework}

H1a. Marketing capital intangibles will positively affect the cost leadership strategy.

H1b. Marketing capital intangibles will positively affect the differentiation strategy.

H2a. Technological capital intangibles is related positively with the cost leadership strategy.

$\mathrm{H} 2 \mathrm{~b}$. Technological capital intangibles is related positively with the differentiation strategy.

H3a. Structural intangibles is related positively with the cost leadership strategy.

$\mathrm{H} 3 \mathrm{~b}$. Structural intangibles is related positively with the differentiation strategy.

Fig. 1 demonstrates the structure of the proposed study.

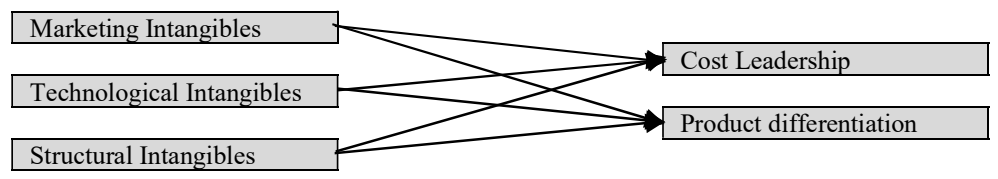

Fig. 1. The proposed conceptual framework

\subsection{Methods}

This study employed survey research design and a questionnaire was used to obtain responses from employees of ten selected money deposit banks within Benin City, Southern Nigeria. Three predictor variables - Marketing capital, technological capital and structural capital combined with one predicted variable i.e. competitive advantage was employed. The instrument consisted of modified 35 item questionnaires made up of Likert type scale statements previously validated and employed in the works of other scholars (e.g. Bontis, 1998; Tovstiga \& Tulugurova, 2007; Sun, 2007; Cater \& Cater, 2009; Khalique et al., 2018). The different variables had the following number of items (Marketing intangibles - 7 items; technological capital - 7 items, structural capital - 9 items, while sustainable competitive advantage - 12 items). Reliability for the various constructs was ascertained through Cronbach's alpha statistics which yielded values between 0.73 and 0.89 for all the variables. All values were above the 0.7 threshold therefore indicating high degree items reliability of the variables. The population of the study were employees of ten money deposit banks in Benin City, Nigeria selected from the approved 22 deposit money banks in Nigeria. A sample size of 300 was adopted for this study. The target respondents were the fully tenured employees involved in the active banking operations. A sum of 300 copies of the research instrument were distributed to the sampled populace across the banks with only 194 properly filled and usable indicating a return rate of approximately $65 \%$ and adjudged as adequate for the study. The hypothesized relationships were tested using regression analysis. The decisions on the hypotheses were reached using the $\mathrm{p}$ - value. The null hypothesis is supported if p-value is greater than 0.05 , while the null hypothesis is not supported where the p-value is less than or equal to 0.05

\subsection{Analysis and Results}

\subsubsection{Reliability values}

The reliability assessment of the various constructs for the study was ascertained using Cronbach's alpha statistics. The coefficient values for all the constructs were between 0.63 and 0.89 . The values were all around the 0.70 threshold therefore indicating high degree constructs reliability (Nunnally, 1978) except for the cost leadership sub component.

Table 1

The results of Cronbach's Alphas

\begin{tabular}{llccc}
\hline & Constructs & No of items & Rating & alpha values \\
\hline 1. & Marketing Intangibles & 7 & $1-5$ & .843 \\
2. & Technological Intangibles & 7 & $1-5$ & .736 \\
3. & Structural capital Intangibles & 9 & $1-5$ & .897 \\
4. & Sustainable competitive advantage & 12 & $1-5$ & .838 \\
& (Differentiation strategy $=0.79)$ & 7 & $1-5$ & \\
& Cost leadership strategy $=0.63)$ & 5 & $1-5$ & \\
\hline
\end{tabular}

Structural equation modelling was employed to evaluate the construct validity of the instrument, while the confirmatory factor analysis was used to ascertain the validity of the measurement and the structural model. The model fit indices are classified into the absolute, relative and parsimonious categories as suggested by Meyers et al. (2006). The results of the confirmatory factor analysis indicate the employed constructs, factor loadings and critical ratio are valid and reliable. The summarized results are presented below. 
Table 2

Summary of Confirmatory Factor Analysis

\begin{tabular}{|c|c|c|c|c|c|c|c|c|c|c|}
\hline & Constructs & $X^{2}$ & $\mathrm{CMIN} / \mathrm{df}$ & RMSEA & GFI & AGFI & CFI & TLI & PNFI & PCFI \\
\hline 1 & Marketing Capital & 41.72 & 2.780 & 0.096 & 0.951 & 0.884 & 0.958 & 0.922 & 0.502 & 0.513 \\
\hline 2 & Technological Capital & 21.47 & 2.146 & 0.077 & 0.969 & 0.914 & 0.973 & 0.944 & 0.454 & 0.464 \\
\hline 3 & Structural Capital & 23.52 & 1.809 & 0.065 & 0.971 & 0.921 & 0.969 & 0.933 & 0.434 & 0.450 \\
\hline 4 & Competitive Advantage & 97.63 & 2.503 & 0.088 & 0.930 & 0.860 & 0.925 & 0.873 & 0.523 & 0.547 \\
\hline
\end{tabular}

The results of fit show that all values for the CMIN/df lie between 1.809 to 2.780 and they are less than the recommended threshold of 5.0; the RMSEA values are from 0.065 to 0.096 and are less than the recommended threshold of 0.1 ; the GFI values were between 0.930 to 0.971 , the AGFI values ranged from 0.86 to 0.92 ; the CFI values stood between 0.925 to 0.973 , and the TLI values were from 0.873 to 0.944 . All values for the GFI, AGFI, CFI and the TLI were around the recommended threshold of 0.9. The PNFI values were from 0.434 to 0.523 while the PCFI values range from 0.450 to 0.547 . Both the PNFI and the PCFI were around the recommended value of 0.5 and above. The results indicate that the data is well suited to the measurement model. Fig. 2 shows the results of the analysis.

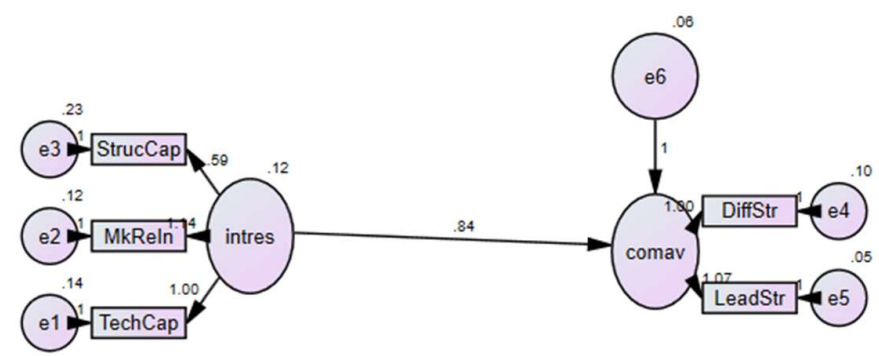

\subsubsection{Hypothesis Testing}

Fig. 2. The results of the analysis

The results of the earlier hypothesized relationships are reported in Table 3 as follows,

Table 3

The results of testing hypotheses

\begin{tabular}{llccrc}
\hline & Hypothesis & $\begin{array}{c}\text { Standardized } \\
\text { coefficient }\end{array}$ & t- value & p value & Results \\
\hline 1a & Marketing intangibles $\rightarrow$ cost leadership strategy & .492 & 6.990 & 0.00 & supported \\
1b & Marketing intangibles $\rightarrow$ differentiation strategy & .449 & 7.845 & 0.00 & supported \\
2a & Technological intangibles $\rightarrow$ cost leadership strategy & .415 & 6.345 & 0.00 & supported \\
2b & Technological intangibles $\rightarrow$ differentiation strategy & .376 & 5.632 & 0.00 & supported \\
3a & Structural capital $\rightarrow$ cost leadership strategy & .373 & 5.580 & 0.00 & supported \\
3b & Structural capital $\rightarrow$ differentiation strategy & .259 & 3.721 & 0.00 & supported \\
\hline
\end{tabular}

Table 4

The results of regression analysis

\begin{tabular}{|c|c|c|c|c|c|c|}
\hline \multirow[b]{2}{*}{ Model } & & \multicolumn{2}{|c|}{ Unstandardized Coefficients } & Standardized Coefficients & \multirow[b]{2}{*}{$\mathrm{t}$} & \multirow[b]{2}{*}{ Sig. } \\
\hline & & $\mathrm{B}$ & Std. Error & Beta & & \\
\hline \multirow[t]{4}{*}{1} & (Constant) & 1.710 & .251 & & 6.816 & .000 \\
\hline & StrucCap & .134 & .047 & .172 & 2.838 & .005 \\
\hline & MkReIn & .317 & .053 & .414 & 6.024 & .000 \\
\hline & TechCap & .137 & .055 & .173 & 2.488 & .014 \\
\hline
\end{tabular}

a. Dependent Variable: CompAdv

$\mathrm{R}$-Square $=0.534$, Adjusted R-Square $=0.344 \mathrm{~F}$-value $=34.925($ Sig. $=0.000)$

The SPSS output results show an $\mathrm{R}^{2}$ value of 0.354 indicating that marketing and techno structural intangible resources to about $35.4 \%$ affects competitive advantage in the sampled banks. The F-value of the model is 34.925 and with a p-value of 0.000. This indicates the suitability of the model used in the study for the data. It further shows that (1- 0.354) i.e. about $64.6 \%$ of competitive advantage in organizations are accounted for by other factors. The relations between the intangible resources studied and competitive advantage is significant at 0.000 . This supports the earlier hypothesized relationships that the sampled intangible resources in aggregation was significantly associated with competitive advantage. The multiple regression output reveals that the marketing, technological and structural intangibles studied were significant. The results agree with findings of studies like Khalique et al. (2018) which affirm that intangibles predominantly influence competitive advantage and performance of organizations. Other scholars like Edelman et al. (2002) and Okpara (2015) further affirmed that organizational/structural capital intangibles affect firms' competitive advantage and performance of firms. Wang and Chang (2005) in 
their study on intellectual capital components and performance in the Taiwanese ICT industry, examined the cause-effects relationship between the intangibles such as structural, human and relational capital and business performances of listed ICT firms in Taiwan for five years. The findings of their study revealed a significant relationship between the intangibles and performance. Similarly, Palacios et al. (2009) studied the effects of intangible resources management on firm entrepreneurship and performance using intangibles such as knowledge, the structure, culture, organizational reputation, brand quality and reputation, patents and trademarks on firm entrepreneurship and performance. A sum of 222 firms from the Spanish biotechnology and telecommunications industry were sampled. The result showed that the intangibles such as knowledge, culture, structure, etc. had positive impact on innovation and entrepreneurship performance of the firms. In the study by Galbreath and Galvin (2008) on the place of intangible resources in explaining performance variations in organizations, intangible resources such as culture, designs, employee management policies and company reputation were examined. Findings show that there was a significant relationship between the intangible organizational resources and eventual firm performance.

\section{Conclusion}

The prime motive of this study was to evaluate and establish whether or not the intangible resources exert influence on competitive advantage in the sampled Nigerian banks using the marketing technological and structural intangible resource dimensions. The results have indicated that all the identified classes of intangible resources studied had some meaningful effects on competitive advantage. The findings have also shown that the marketing, technological and structural intangibles were the key components of intangible capital and would predict competitive advantage. In the view of the above, the banks may take advantage of this and engage in promoting and development of their intangible capital.

\subsection{Implications for the Industry}

The findings have practical implications for the banking sector and other allied institutions in Nigeria. The results suggest that for banks to build competitive edge, priority attention and commensurate significant investments must be given to intangible resources development in the banks. In addition, the bank management ability to identify and promote factors that will enhance its marketing and techno structural intangibles resource base would facilitate competitive advantage both locally and globally.

\subsection{Implications for the Government and Policy Makers}

The implications for policy makers are that this study again reemphasizes on the role of intangible capital in competitiveness and performance, both for the industry regulators and the government. Thus, the formation and pursuance of strategic policies that would support the development of intangible capital both at the micro and macro level are therefore paramount. Further works on the development of intangible resources and competitive advantage in Nigeria are recommended. Other aspects of intangible resources may also be studied to establish their effects on competitive advantage development in the Nigerian banking sector. This will contribute to the extant literature on this subject in an emerging economy like Nigeria. Studies of this nature may also be conducted in other sectors of the economy to ascertain the results. Related studies may also be replicated in the banking sector of other developing economies in the African continent.

\section{References}

Adler, P. S., \& Kwon, S. W. (2002). Social capital: Prospects for a new concept. Academy of Management review, 27(1), 17-40.

Almor, T., \& Hashai, N. (2004). The competitive advantage and strategic configuration of knowledge- intensive, small-and medium-sized multinationals: a modified resource-based view. Journal of International Management, 10(4), $479-500$.

Amiri, A. N., Jandghi, G., Alvani, S. M., Hosnavi, R., \& Ramezan, M. (2010). Increasing the intellectual capital in organization: Examining the role of organizational learning. European Journal of Social Sciences, 14(1), 98-108.

Andrews, D., \& De Serres, A. D. (2012). Intangible Assets, Resource Allocation and Growth. OECD Economics Department Working Papers

Barnabas, S. S., Nwuche, C. A., \& Anyanwu, S. (2016). Intellectual Capital and Organizational Survival of Selected Banks in Rivers State, Nigeria. The International Journal of Business \& Management, 4(1), 258.

Blair, M.M., \& Wallman, S.M.H. (2001), Unseen Wealth - Report of the Brookings Task Force on Intangibles, The Brookings Institution, Washington, DC.

Bontis, N. (1998). Intellectual capital: an exploratory study that develops measures and models. Management decision, 36(2), 63-76.

Boubakri, N., \& Ghouma, H. (2008). Managerial opportunism, cost of debt financing, and regulation changes: Evidence from the Sarbanes-Oxley Act adoption. Available at SSRN 1127351.

Cater, T., \& Pucko, D. (2006). Models of competition between firms: The case of Slovenia's (post) transitional economy. Journal for East European Management Studies, 11(2), 140-172.

Chahal, H., \& Bakshi, P. (2014). Effect of intellectual capital on competitive advantage and business performance: role of innovation and learning culture. International Journal of Learning and Intellectual Capital, 11(1), 52-70. 
Edelman, L. F., Brush, C. G., \& Manolova, T. (2002). The mediating role of strategy on small firm performance. Journal of Business venturing, 4(3), 27-35.

Edvinsson, L. (2007). Intellectual Capital: The proven way to establish your company's real values by measuring its hidden brainpower. London: Harper Business.

Fernández, E., Montes, J. M., \& Vázquez, C. J. (2000). Typology and strategic analysis of intangible resources: A resourcebased approach. Technovation, 20(2), 81-92.

Galbreath, J., \& Galvin, P. (2008). Firm factors, industry structure and performance variation: New empirical evidence to a classic debate. Journal of Business Research, 61(2), 109-117.

Gomez-Mejia, L.R., \& Balkin, D.B. (2002). Management. McGraw-Hill: New York, NY.

Guenther, T.W., Beyer, D., \& Menninger, J. (2005). Hurdles for the voluntary disclosure of information on intangibles empirical results for "new economy” industries. Dresden Papers of Business Administration, No. 71/03

Husain, Z., Altameem, A. A., \& Gautam, V. (2013). Technology based management of customer relational capital: humantouch still a necessity. Journal of Services Research, 13(1), 53-74.

Hatch, N. W., \& Dyer, J. H. (2004). Human capital and learning as a source of sustainable competitive advantage. Strategic Management Journal, 25(12), 1155-1178.

Khalique, M., Bontis, N., Shaari, J. A. N. B., Yaacob, M. R., \& Ngah, R. (2018). Intellectual capital and organisational performance in Malaysian knowledge-intensive SMEs. International Journal of Learning and Intellectual Capital, 15(1), 20-36.

Kotler, P., \& Armstrong, G. (2010). Principles of marketing. Pearson education.

Kotler, P. \& Keller, K. L. (2011). Marketing Management, Saddle River, New Jersey: Prentice Hall Publishers.

Maddocks, J., \& Beaney, M. (2002). See the invisible and intangible. Knowledge Management, 16-17.

McGrattan, E.R., \& Prescott, E.C. (2008). Openness, technology capital, and development. Federal Reserve Bank of Minneapolis Research Department Staff Report, 396

Meritum, P. (2002). Guidelines for managing and reporting on intangibles. Fundación Airtel-Vodafone.

Meyers, L. S., Gamst, G., \& Guarino, A. J. (2016). Applied multivariate research: Design and interpretation. Sage publications.

Montresor, S., Perani, G., \& Vezzani, A. (2014). How do companies 'perceive' their intangibles? New statistical evidence from the INNOBAROMETER 2013. Institute for Prospective Technological Studies. European Commission.

Nunnally, J. C. (1978). Psychometric theory (2 ${ }^{\text {nd }}$ ed.). New York: McGraw-Hill.

Okpara, J. O. (2015). Exploring the effects of intangible resources on competitive advantage and performance of listed firms in Nigeria. Business and Applied Sciences Academy of North America, 8.

Lev, B. (2003). Intangibles: Management, Measurement and Reporting. Moscow: Cwinto- Consulting.

Lev, B. (2001). Intangibles: Management, Measurement and Reporting. Washington, DC: the Brookings Institute

Palacios, D., Gil, I., \& Garrigos, F. (2009). The impact of knowledge management on innovation and entrepreneurship in the biotechnology and telecommunications industries. Small Business Economics, 32(3), 291-301.

Perez, M. M. \& Famá, R. (2006). Ativos intangíveis e o desempenho empresarial. Revista Contabilidade \& Finanças, 17(40), 7-24.

Perrini, F., \& Vurro, C. (2010). Corporate sustainability, intangible assets accumulation and competitive advantage constraints. Symphonya. Emerging Issues in Management, (2), 25-38.

Pierre, J.S. (2011). Intangible assets and performance analysis on manufacturing SMEs. Journal of Intellectual Capital, 12(2), 202-223.

Porter, M. (1995). 'What is Strategy?' Harvard Business Review, 74(6), 61-78.

Porter M. (2005). Competitive advantage: How to achieve good result and ensure its stability. M.: Publishing House "Alpina Business Books".

Porter, M. E. (2008). The five competitive forces that shape strategy. Harvard business review, 86(1), 25-40.

Saeed, S., Rasid, S. Z. A., \& Basiruddin, R. (2016). Relationship between intellectual capital and corporate performance of top Pakistani companies: an empirical evidence. International Journal of Learning and Intellectual Capital, 13(4), 376396.

Satt, H. (2015). The Impact of positive cash operating activities on bonds' pricing: International Evidence. Journal of Corporate and Ownership Control, 12(2015), 708-717.

Satt, H., \& Tamek, A. (2017). Marketing intangible assets and credit ratings, evidence from MENA. Risk Governance \& Control: financial markets \& institutions, 7(2,1), 214-223.

Serenko, A. \& Bontis, N. (2004). Meta-review of knowledge management and intellectual capital literature: citation impact and research productivity ranking. Knowledge and Process Management, 11(3).

Serenko, A., Bontis, N., \& Grant, J. (2009). A scientometric analysis of the proceedings of the McMaster world congress on the management of intellectual capital and innovation for the 1996-2008 period. Journal of Intellectual Capital, 10(1), $8-21$.

Grigoriev, S. N., Yeleneva, J. Y., Golovenchenko, A. A., \& Andreev, V. N. (2014). Technological capital: a criterion of innovative development and an object of transfer in the modern economy. Procedia CIRP, 20, 56-61.

Starovic, D. \& Marr, B. (2003). Understanding corporate value: managing and reporting intellectual capital. Technical Report. Chartered Institute of Management Accountants (CIMA) Publications.

Steward, A. (2010). Intellectual Capital: The new wealth of organizations. [Kindle Edition]. New York: Crown Business. 
Stewart, T. A. (1999). Intellectual capital: the new wealth of organizations. New York: Doubleday Publishers.

Sun, P.C. (2007). Correlations among domain knowledge specificity, joint new product development and relationship performance: International Journal of Commerce \& Management, 17(1-2) 44-55.

Teixeira, J. P., Petri, S. M., \& Marques, T. O. (2012). O valor da marca como um ativo intangível: um estudo de caso da WEG S.A. Revista de Contabilidade do Mestrado em Ciências Contábeis da UERJ, 17(2), 45-67.

Tovstiga, G., \& Tulugurova, E. (2007). Intellectual capital practices and performance in Russian enterprises. Journal of Intellectual Capital, 8(4), 695-707.

Villalonga, B. (2004). Intangible resources, Tobin'sq, and sustainability of performance differences. Journal of Economic Behavior \& Organization, 54(2), 205-230.

Volkov, D., \& Garanina, T. (2007). Intangible Assets: Importance in the Knowledge-Based Economy and the Role in Value Creation of a Company. Electronic Journal of Knowledge Management, 5(4).

Wade, M., \& Hulland, J. (2004). The resource-based view and information systems research: Review, extension, and suggestions for future research. MIS quarterly, 28(1), 107-142.

Wang, W.Y. \& Chang, C. (2005). Intellectual capital and performance in causal models: evidence from the information technology industry in Taiwan. Journal of Intellectual Capital, 6(2), 222-36.

Youndt, M. A. \& Scott, A. S. (2004). Human resources configurations, intellectual capital, and organizational performance. Journal of Management Issues, 16(3), 337-361.

Zangoueinezhad, A., \& Moshabaki, A. (2009). The role of structural capital on competitive intelligence. Industrial Management \& Data Systems, 109(2), 262-280.

\section{Appendix 1}

Survey instrument for effect of marketing and technological intangible resources on competitiveness in Nigerian Banks

\begin{tabular}{|c|c|c|c|c|c|c|}
\hline & \multirow{2}{*}{$\begin{array}{lr} & \text { STATEMENTS } \\
\text { Marketing Capital. }\end{array}$} & \multicolumn{5}{|c|}{ RESPONSES } \\
\hline & & SD & D & UD & A & SA \\
\hline 1 & Our bank brand is well recognized by customers & & & & & \\
\hline 2 & Our customers remain loyal to us over the years & & & & & \\
\hline 3 & Our customers display commitment & & & & & \\
\hline 4 & Our organization enjoys favorable reputation in the market & & & & & \\
\hline 5 & Our market share in the industry is growing & & & & & \\
\hline 6 & Our internet/online banking is reputed as most user friendly & & & & & \\
\hline \multirow[t]{2}{*}{7} & There is huge potential for new markets in the industry. & & & & & \\
\hline & Technological Capital & & & & & \\
\hline 8 & Our bank technology is preferred by the customers & & & & & \\
\hline 9 & Our bank has legally-protected designs & & & & & \\
\hline 10 & Our bank has legally-protected trademarks & & & & & \\
\hline 11 & We are constantly investing in generating new capabilities that give us an advantage over to our competitors & & & & & \\
\hline 12 & If ever there was a new way of serving customers, our company would be able to offer it & & & & & \\
\hline 13 & Our bank has proprietary / held-in-secret technology such as customized software not available to the competitors. & & & & & \\
\hline \multirow[t]{2}{*}{14} & Our bank has specialized services and technological, software developed in-house, etc. & & & & & \\
\hline & Structural Capital. & SD & D & UD & $\mathbf{A}$ & SA \\
\hline 15 & Our information system enables employees to have easy access to relevant information. & & & & & \\
\hline 16 & We develop new ideas and products/services than any other bank in the industry. & & & & & \\
\hline 17 & When an employee comes up with a new idea, the knowledge is not shared with other employees as much as it could be. & & & & & \\
\hline 18 & Our bank has a good operating structure & & & & & \\
\hline 19 & Our bank has an excellent reporting structure & & & & & \\
\hline 20 & We have good physical equipment and other physical assets like computers, machinery, tools, vehicles, etc. & & & & & \\
\hline 21 & $\begin{array}{l}\text { Our advantages are embodied in the company and not in individuals - nobody can copy us by stealing our employees away from } \\
\text { us }\end{array}$ & & & & & \\
\hline 22 & Nobody can copy our corporate routines, processes and culture & & & & & \\
\hline \multirow[t]{2}{*}{23} & Our internal structure supports employee interactions with each other so they can better co-operate & & & & & \\
\hline & Competitive Advantage (Cost-Leadership and Differentiation Based) & SD & D & UD & $\mathbf{A}$ & SA \\
\hline 24 & Our costs/ service charges per unit service are lower than our competitors' costs. & & & & & \\
\hline 25 & We have been continually improving our cost efficiency. & & & & & \\
\hline 26 & We pride ourselves on being cost efficient & & & & & \\
\hline 27 & Our business strategies are driven by our beliefs about how we can create greater value for customers & & & & & \\
\hline 28 & We target customers where we have an opportunity for competitive advantage & & & & & \\
\hline 29 & Our services are unique and nobody but our bank can offer them & & & & & \\
\hline 30 & In comparison with our competitors the quality of our services are much better. & & & & & \\
\hline 31 & In comparison with our competitors we are faster in satisfying our customers' needs / customer complaints. & & & & & \\
\hline 32 & In comparison with our competitors we are more flexible in satisfying our customers' needs & & & & & \\
\hline 33 & We measure customer satisfaction systematically and frequently & & & & & \\
\hline 34 & Our strategy for competitive advantage is based on our understanding of customer's needs & & & & & \\
\hline 35 & Our bank offers service-based advantages that are reliable, flexible and fast and affords great value for the customer & & & & & \\
\hline
\end{tabular}

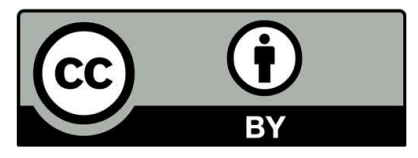

(C) 2020 by the authors; licensee Growing Science, Canada. This is an open access article distributed under the terms and conditions of the Creative Commons Attribution (CCBY) license (http://creativecommons.org/licenses/by/4.0/). 